F. Reprod. Fert. (1967) 13, 205-212

\title{
A MECHANISM ANTAGONIZING THE LUTEOTROPHIC ACTION OF EXOGENOUS PROLACTIN IN RATS
}

\author{
P. V. MALVEN*, W. HANSEL AND C. H. SAWYER \\ Department of Anatomy and Brain Research Institute, University of California, \\ Los Angeles, California, and Department of Animal Husbandry, \\ Cornell University, Ithaca, New York
}

(Received 1st February 1966)

\begin{abstract}
Summary. The luteotrophic action of injected prolactin appears to be antagonized by an endogenous luteolytic mechanism to such an extent that the functional life-span of the corpora lutea cannot be lengthened more than 3 days beyond that of the non-injected control. This type of antagonism was seen in both intact and hysterectomized pseudopregnant rats and in lactating rats deprived of their litters. The antagonism was not observed in hypophysectomized rats, in which prolactin injections maintained functional corpora lutea for at least 20 days after ovulation. These results suggest the existence of a hypophysial hormone capable of antagonizing endogenous as well as exogenous prolactin.

Hysterectomy may affect the timing of the luteolytic mechanism, but the latter seems to operate effectively in the absence of uterine stimuli. Luteolysis is apparently inhibited during lactation, but removal of the suckling stimulus results in a prompt activation of the process.

In control experiments with untreated lactating rats, litter removal 8 or 12 days post partum terminated luteal secretory function on Day 14 regardless of when the litters were removed. These results suggest that 7-day-old corpora lutea of lactation respond less quickly than 11-dayold corpora to the endogenous hormonal alterations resulting from litter removal.
\end{abstract}

\section{INTRODUCTION}

The early experiments which demonstrated the luteotrophic action of prolactin also revealed that the hormone could not maintain functional corpora lutea indefinitely (Dresel, 1935; Lahr \& Riddle, 1936). In spite of continued prolactin administration in either mice or rats, the animals returned to oestrus in these early studies. The corpora lutea may have become exhausted or unresponsive to prolactin. Antibodies formed in response to the foreign proteins may have also inhibited the action of the injected prolactin. Recent experiments (Everett, 1956; Quilligan \& Rothchild, 1960) with pituitary grafts, which

* Postdoctoral fellow (NB 23,284) of the National Institutes of Health. Present address: Department of Animal Sciences, Purdue University, Lafayette, Indiana, U.S.A. 
probably secrete prolactin continuously, have shown that the corpora lutea are maintained indefinitely only in animals lacking an intact hypothalamopituitary axis.

The present experiments were designed to answer the limited question of whether enhanced prolactin secretion might account entirely for the increased corpus luteum life-span in hysterectomized pseudopregnant rats. The results have answered the original question negatively and have also provided evidence for a mechanism antagonizing the luteotrophic action of injected prolactin.

\section{MATERIALS AND METHODS}

These experiments were conducted on mature Sprague-Dawley (170 to $250 \mathrm{~g}$ ) female rats. Vaginal smears were obtained by lavage and examined in the unstained state. The day of ovulation at the termination of corpus luteum function was determined by combining evaluation of vaginal smears, observation of tubal ova and histological examination of the ovaries.

Pseudopregnancy was initiated by electrical stimulation of the cervix on the night of a pro-oestrous vaginal smear (Day 0 ). Hysterectomies were performed under ether on Day 2 in the manner previously reported (Malven \& Hansel, 1965). The number of days between the initial ovulation (early on Day 1) and the terminal one was taken as a measure of the functional life-span of the corpora lutea.

In the experiments with lactating rats, litter size was adjusted to eight on the day after parturition (Day 1 ). These eight pups were removed from the mother's cage on the morning of Day 8 or Day 12. Prolactin injections were begun on the day of pup removal, and vaginal smears were initiated the following day.

In most of the experiments, prolactin was suspended in saline or distilled water and injected subcutaneously once daily. The preparations were frozen if they were to be stored more than 4 days, but usually the suspension was kept at $5^{\circ} \mathrm{C}$ and used daily for 4 days. In one experiment, prolactin was suspended in the slow-release medium of sesame oil and $5 \%$ beeswax reported to potentiate the activity of ACTH by releasing it slowly and uniformly (Bruce \& Parkes, 1952). The medium was stored at $5^{\circ} \mathrm{C}$ in a semi-solid state and was melted by heating ( 45 to $50^{\circ} \mathrm{C}$ ) each day for injection. An individual preparation was never heated more than five times.

Several different prolactin preparations were used in these experiments. Armour Pharmaceutical Company generously prepared and assayed an ovine preparation which was used for the slow-release experiment. The other experiments were performed with NIH standards S- 5 and S- 6 supplied by the Endocrinology Study Section, National Institutes of Health.

In the two experiments with mature hypophysectomized rats, the animals (140 to $160 \mathrm{~g}$ ) were purchased from a commercial supplier. Ovulation was induced by an FSH-LH treatment regimen begun 1 to 2 weeks after hypophysectomy. In Trial I, a commercial FSH preparation (Armour FSH-P) was injected subcutaneously for 4 days at a dosage of $350 \mu \mathrm{g}$ Armour Standard/day. Ovulation was induced with a single subcutaneous injection of a special preparation of ovine LH on the 4th day. The ability of this regimen to induce rupture of the 
follicles was not verified, but the response to prolactin clearly indicated the presence of new luteal tissue. In Trial II, the animals received $119 \mu \mathrm{g} /$ day FSH (NIH-S-3) for 4 days and $200 \mu \mathrm{g} \mathrm{LH}$ (NIH-S-8) on the 4th day. This treatment has been shown in another study (Malven \& Sawyer, 1966b) to induce marked ovarian enlargement, follicular rupture and formation of corpora lutea as well as intense luteinization of unruptured follicles. Prolactin injections were begun $24 \mathrm{hr}$ after the LH injection and continued until necropsy. One uterine horn was traumatized in these animals 4 days before necropsy. A needle was inserted into the uterine lumen and withdrawn so as to scratch 2 to $3 \mathrm{~cm}$ of the antimesometrial side. The needle was then used to place a thread lengthwise through this portion of the horn and tie it loosely in place.

\section{RESULTS}

Table 1 summarizes the experiments in which prolactin was administered to intact and hysterectomized rats during pseudopregnancy. The mean duration of pseudopregnancy in intact and hysterectomized controls agrees well with the findings of previous investigations (Malven \& Hansel, 1965). Prolactin administered once or twice daily to intact rats significantly lengthened (by 2 to 3 days,

TABLE 1

EFFECT OF INJECTED PROLACTIN ON THE FUNGTIONAL LIFE-SPAN OF PSEUDOPREGNANCY CORPORA LUTEA

\begin{tabular}{l|c|c|c|c}
\hline & $\begin{array}{c}\text { Daily } \\
\text { dosage }\end{array}$ & $\begin{array}{c}\text { Day of } \\
\text { initial } \\
\text { injection }\end{array}$ & $\begin{array}{c}\text { No. } \\
\text { rats }\end{array}$ & $\begin{array}{c}\text { Interval } \\
\text { between } \\
\text { ovulations } \dagger\end{array}$ \\
\hline $\begin{array}{l}\text { Intact pseudopregnant } \\
\text { Controls }\end{array}$ & - & - & 19 & $12 \cdot 8$ \\
Aqueous prolactin & 10 & 1 & 8 & $15 \cdot 5 * *$ \\
& $20 \ddagger$ & 1 & 10 & $14 \cdot 5 * *$ \\
Prolactin in oil & 10 & 5 & 9 & $13 \cdot 3$ \\
& 10 & 9 & 8 & $14 \cdot 1^{*}$ \\
Hysterectomized & 10 & 1 & 8 & $13 \cdot 0$ \\
Controls & 10 & 9 & 8 & $12 \cdot 6$ \\
\hline Aqueous prolactin & - & - & 18 & $17 \cdot 2$ \\
\hline
\end{tabular}

† Significance tested by Dunnett's test $\left(\mathrm{SD}=1.3\right.$ days) $:^{*} P<0.05 ; * * P<0.01$.

$\$$ Administered as twice daily injections.

$P<0 \cdot 01$, Dunnett's Test; Steel \& Torrie, 1960) the functional life of the pseudopregnancy corpora lutea when the injections were begun on the 1st day of pseudopregnancy. Aqueous prolactin injections begun later or injections of the prolactin in a slow-release medium had little if any effect on corpus luteum life-span.

Since exogenous prolactin did not increase the duration of pseudopregnancy to the 17-day interval characteristic of hysterectomy, our original question about enhanced prolactin secretion was answered: an increased or prolonged secretion of prolactin cannot entirely account for the extended corpus luteum 
life-span in hysterectomized pseudopregnant animals. Furthermore, these results suggested the possibility of an antagonism to the injected prolactin exerted by an endogenous luteolytic mechanism.

The mechanism antagonizing the luteotrophic action of injected prolactin could not be demonstrated in the absence of the pituitary (Table 2). Prolactin treatment, identical to that which failed to extend corpus luteum life-span past 15 days in pseudopregnant rats, successfully maintained functional corpora lutea for 14 and 20 days respectively. The induction of ovulation by the FSH and LH regimen in Trial I was not confirmed, and it appears likely that one of the five animals did not ovulate. Not only were large deciduomata absent, but the ovarian weight was markedly reduced in the manner shown to occur when

\section{TABLE 2}

EFFECT OF INJEGTED PROLACTIN ON THE FUNCTIONAL LIFE-SPAN OF INDUCED CORPORA LUTEA IN HYPOPHYSEGTOMIZED RATS

\begin{tabular}{|c|c|c|c|c|c|}
\hline & \multicolumn{2}{|c|}{$\begin{array}{c}\text { Days after } \\
\text { induced ovulation* }\end{array}$} & \multirow{2}{*}{$\begin{array}{c}\text { Incidence } \\
\text { of large } \\
\text { deciduomata }\end{array}$} & \multirow{2}{*}{$\begin{array}{l}\text { Increase in weight } \\
\text { of traumatic } \\
\text { uterine horn }(\mathrm{mg})\end{array}$} & \multirow{2}{*}{$\begin{array}{c}\text { Ovarian } \\
\text { weight }(\mathrm{mg})\end{array}$} \\
\hline & Trauma & Necropsy & & & \\
\hline $\begin{array}{l}\text { Trial I } \\
\text { Control } \\
\text { Prolactin } \dagger\end{array}$ & $\begin{array}{l}10 \\
10\end{array}$ & $\begin{array}{l}14 \\
14\end{array}$ & $\begin{array}{l}0 / 4 \\
3 / 5\end{array}$ & $\begin{array}{r}7 \cdot 3 \\
38 \cdot 8\end{array}$ & $\begin{array}{l}25 \cdot 9 \\
22 \cdot 3\end{array}$ \\
\hline $\begin{array}{l}\text { Trial II } \\
\text { Control } \\
\text { Prolactin } \ddagger\end{array}$ & $\begin{array}{l}16 \\
16\end{array}$ & $\begin{array}{l}20 \\
20\end{array}$ & $\begin{array}{l}0 / 4 \\
3 / 3\end{array}$ & $\begin{array}{r}6 \cdot 0 \\
212 \cdot 6\end{array}$ & $\begin{array}{l}69 \cdot 7 \\
74 \cdot 7\end{array}$ \\
\hline
\end{tabular}

* Trial I. $350 \mu \mathrm{g} /$ day Armour Standard FsH-P for 4 days and $160 \mu \mathrm{g}$ of special ovine LH preparation on the 4th day. Trial II. $119 \mu \mathrm{g} /$ day FSH (NIH-S-3) for 4 days and $200 \mu \mathrm{g} \mathbf{~ H}$ (NIH-S-8) on the 4th day.

$\dagger 10$ i.u./day aqueous prolactin (ovine) prepared by Armour Pharmaceutical Company. Begun on Day 1.

$\$ 10$ i.u./day aqueous prolactin (NIH-S-6). Begun on Day 1 .

prolactin is administered to hypophysectomized rats possessing only nonfunctional corpora (Malven \& Sawyer, 1966a). In the only other animal which failed to possess a large deciduoma in Trial I, a histological decidual reaction could be detected. In all three treated rats in Trial II, prolactin caused the many corpora lutea produced by the FSH-LH regimen to secrete sufficient progesterone to support massive deciduomata.

In the functional corpora lutea maintained by prolactin, the lutein cell nuclei were larger and more spherical than they were in non-functional corpora. The nuclei were also less densely basophilic and contained more prominent nucleoli. Another feature of functional corpora was a granular cytoplasm.

The ovaries of prolactin-treated rats contained only one generation of corpora lutea while several generations could be observed in control animals. The luteolysis induced by prolactin in the non-functional corpora formed before hypophysectomy (Malven \& Sawyer, 1966a) clearly accounts for this absence of older generations in prolactin-treated rats. The luteotrophic action 
of prolactin on the induced corpora and its luteolytic action on pre-existing non-functional ones probably balance each other and prevent any significant changes in ovarian weight.

After the failure to demonstrate an antagonistic mechanism in hypophysectomized animals, it seemed important to test for its presence in hysterectomized pseudopregnant animals. The inability of injected prolactin to extend the life of the corpora lutea beyond the normal 17 days (last line of 'Table 1) indicates that the termination of corpus luteum function in the hysterectomized pseudopregnant rat is not due to reduced prolactin secretion. The results with both prolactin-treated and control animals demonstrate that the luteolytic mechanism can operate in the complete absence of uterine stimuli. These results do not rule out the possibility that uterine stimuli can trigger or enhance the mechanism.

The extended life-span of corpora lutea in lactating rats suggests that lactation inhibits the mechanism which antagonizes the luteotrophic effect of prolactin. Assuming this to be true, we conducted the experiment presented in Table 3 to determine how long such an inhibition would last following removal of the

TABLE 3

EFFECT OF INJECTED PROLACTIN ON THE LIFE-SPAN OF POST-PARTUM CORPORA LUTEA AND OVARIAN WEIGHTS IN LAGTATING RATS DEPRIVED OF THEIR LITTERS $\dagger$

\begin{tabular}{l|c|c|c|c}
\hline & $\begin{array}{c}\text { No. } \\
\text { rats }\end{array}$ & $\begin{array}{c}\text { Day of second } \\
\text { post-partum } \\
\text { ovulation }\end{array}$ & $\begin{array}{c}\text { Interval } \\
\text { from removal } \\
\text { to ovulation }\end{array}$ & $\begin{array}{c}\text { Ovarian weight } \\
100 \mathrm{~g} \text { body } \\
\text { weight (mg/g) }\end{array}$ \\
\hline $\begin{array}{c}\text { Pups removed Day 12 } \\
\begin{array}{c}\text { Non-injected } \\
\text { Prolactin-treated } \\
\text { (10 i.u./day) }\end{array}\end{array}$ & 8 & $14 \cdot 1$ & $2 \cdot 1$ & $38 \cdot 2$ \\
\hline $\begin{array}{c}\text { Pups removed Day 8 } \\
\text { Non-injected } \\
\text { Prolactin-treated } \\
\text { (10 i.u/day) }\end{array}$ & 9 & $16 \cdot 6 * *$ & $4 \cdot 6 * *$ & $34 \cdot 1^{*}$ \\
\hline
\end{tabular}

† Significance tested by Duncan's New Multiple Range Test: ${ }^{*} P<0.05 ;{ }^{* *} P<0.01$.

suckling stimulus. In rats deprived of their litters on Day 12, prolactin injections delayed ovulation only 2.5 days $(P<0.01$, Duncan's test, Steel \& Torrie, 1960). Apparently, the previously inhibited luteolytic mechanism recovered sufficiently within 4 to 5 days to antagonize the luteotrophic action of the injected prolactin. In rats deprived of their litters on Day 8, prolactin failed to lengthen significantly the corpus luteum life-span, perhaps because the luteolytic mechanism had more time in which to recover from its lactation-induced inhibition.

The observation was quite unexpected that the second post-partum ovulation occurred on Day 14 in untreated controls regardless of whether the pups were removed on Days 8 or 12. If one assumes that the first post-partum ovulation occurred on Day 1 (Hoffman \& Schwartz, 1965) then the lactational corpora lutea had an average life-span of 13 days, exactly the same as in intact pseudo- 
pregnant rats. When the pups were removed from four other untreated rats on Day 4, three of them also maintained corpora lutea for this duration (Days 11 to 13), while one ovulated on Day 8. This phenomenon of complete pseudopregnancies following very early litter removal was also observed by Alloiteau (1962). He further showed that communal caging and the immediate taking of vaginal smears increased the incidence of such pseudopregnancies. Our high incidence in the Day 4 animals may have resulted from the taking of daily smears. The importance of vaginal smearing in the Day 8 group cannot be determined but it is believed to be minimal.

In four of twelve rats deprived of their litters on Day 8 , the vaginal smears contained large numbers of cornified or mucified cells on Day 10. These four rats were killed at this time; three of them did not possess new corpora lutea and were, therefore, excluded from Table 3. These four rats as well as others showing similar but less pronounced changes in their vaginal smears on Day 10 indicate oestrogenic stimulation at this time.

The decrease of ovarian weights $(P<0.05)$ in prolactin-treated rats (Table 3 ) at necropsy agrees well with the recent and unusual finding of prolactininduced luteolysis in the nonfunctional corpora lutea of hypophysectomized rats (Malven \& Sawyer, 1966a). Histological examination of the ovaries in the present study revealed that the corpora lutea of pregnancy were of a smaller size in prolactin-treated rats. This size difference was especially pronounced in the Day 8 group which had received prolactin for a longer period. A similar case of prolactin-accelerated luteolysis of pregnancy corpora was reported by Long \& Evans (1922); they removed the pups at birth and observed a slower rate of luteolysis than that seen in lactating rats.

\section{DISGUSSION}

The inability of injected prolactin to prolong indefinitely the functional life of rat corpora lutea is not a new observation. Lahr \& Riddle (1936) reported that rats returned to oestrus after 12 to 15 days of continuous injections. Aschheim (1954) observed pseudopregnancies averaging 11 days in prolactintreated rats. Prolactin injections also failed to maintain the function of pregnancy corpora lutea when both gravid horns were removed during the second half of gestation (Mayer \& Klein, 1949b). The ability of injected prolactin to extend the normal life span of pregnancy corpora lutea has been both affirmed (Meites \& Shelesnyak, 1957) and denied (Mayer \& Klein, 1949a).

All of these failures with injected prolactin could be explained as resulting from unresponsiveness of the corpora lutea or from inactivation of the injected hormone by antibodies. The classic experiments of Everett (1956) with rats bearing autografted pituitaries showed clearly for the first time that corpora lutea could be kept functional for several months by hypophysial luteotrophin alone. With the question of luteal unresponsiveness eliminated, the possibility of a physiological antagonism became more reasonable. Quilligan \& Rothchild (1960) demonstrated the presence of such a mechanism in the rat when they eliminated the antibody problem and were still able to show an antagonism. In their experiments, luteotrophin secreted by a pituitary homograft was 
antagonized by some factor related to the in-situ pituitary. Later experiments (Rothchild, 1965a) suggest that this factor was LH.

The present experiments have confirmed the dependence of the prolactin antagonism on an intact hypothalamo-pituitary axis. The same prolactin preparation in dosages that were unable to extend markedly the corpus luteum life-span in pseudopregnant rats could maintain functional corpora lutea for as long as 20 days in hypophysectomized animals. Nelson (1946) observed a similar duration of luteal maintenance in prolactin-treated hypophysectomized rats. However, no one has continued the exogenous prolactin longer than 20 days.

A recent review (Rothchild, 1965b) suggests that the luteotrophic process may involve a combination of some hormones as well as the absence of others. On the other hand, the luteolytic process in the rat consists of two distinct states. Initially, luteolysis is a functional process by which secretory activity is terminated, and secondarily, morphological changes appear which lead to the total disappearance of the glandular tissue (Everett, 1961). The luteolytic mechanism considered in the present experiments represents only the first phase, the termination of luteal secretory function. Malven \& Sawyer (1966a) have recently demonstrated that the second or morphological phase of luteolysis is markedly hastened by prolactin administration. The apparent paradox of the same hormone opposing (although somewhat ineffectively) the first phase of luteolysis while hastening the second has not been completely resolved, but Malven \& Sawyer (1966a) have postulated that the response of the corpora lutea to prolactin depends on conditions present within the luteal tissue. It is possible that the luteolytic hormone of the first phase terminates the luteal secretory function by antagonizing the luteotrophic action of prolactin and, in doing so, prepares the non-functional luteal tissue to respond to the luteolytic action of prolactin.

\section{ACKNOWLEDGMENT}

This work was supported by Grant NB 01162 from the National Institutes of Health.

\section{REFERENCES}

Allorteau, J. J. (1962) Le contrôle hypothalamique de l'adenohypophyse. III. Régulation de la fonction gonadotrope femelle activité LTH. Biologie méd. 51, 250.

Aschнетм, P. (1954) Influence du tissu décidual sur la pseudogestation provoquée par l'administration de prolactine chez le rat. C. r. Séanc. Soc. Biol. 148, 185.

Bruce, H. M. \& PARkes, A. S. (1952) A slow-release medium for adrenocorticotrophic hormone. Lancet, $\mathbf{i}, 71$.

DreseL, I. (1935) The effect of prolactin on the estrous cycle of non-parous mice. Science, N.Y. 82, 173.

EveretT, J. W. (1956) Functional corpora lutea maintained for months by autografts of rat hypophyses. Endocrinology, 58, 786.

Everetr, J. W. (1961) The mammalian female reproductive cycle and its controlling mechanisms. Sex and Internal Secretions, Vol. I, p. 497. Ed. W. C. Young. Williams \& Wilkins, Baltimore.

Hoffman, J. C. \& Schwartz, N. B. (1965) Timing of post-partum ovulation in the rat. Endocrinology, 76, 620 .

LAHR, E. L. \& RidDle, O. (1936) Temporary suppression of estrous cycles in the rat by prolactin. Proc. Soc. exp. Biol. Med. 34, 880.

Long, J. A. \& Evans, H. M. (1922) The oestrous cycle in the rat. Mem. Univ. Calif. 6, 1. 
Malven, P. V. \& Hansel, W. (1965) Effect of bovine endometrial extracts, vasopressin and oxytocin on the duration of pseudopregnancy in hysterectomized and intact rats. $\mathcal{7}$. Reprod. Fert. 9, 207.

Malven, P. V. \& SAwYeR, G. H. (1966a) A luteolytic action of prolactin in hypophysectomized rats. Endocrinology, 79, 268.

Malven, P. V. \& Sawyer, C. H. (1966b) Formation of new corpora lutea in mature hypophysectomized rats. Endocrinology, 78, 1259.

Mayer, G. \& Klein, M. (1949a) Effets de l'administration de prolactine en fin de grossesse chez la ratte. C. r. Séanc. Soc. Biol. 143, 1195.

Mayer, G. \& Klein, M. (1949b) Administration de prolactine et ablation des cornes gravides chez la ratte. C. r. Séanc. Soc. Biol. 143, 1197.

Meites, J. \& Sheiesnyak, M. C. (1957) Effects of prolactin on duration of pregnancy, viability of young and lactation in rats. Proc. Soc. exp. Biol. Med. 94, 746.

Nelson, W. O. (1946) Factors concerned in the maintenance of function of the corpus luteum. (Abstract). Endocrinology, 39, 66.

Quilligan, E. J. \& Rothchild, I. (1960) The corpus luteum-pituitary relationship: The luteotrophic activity of homotransplanted pituitaries in intact rats. Endocrinology, 67, 48.

RoтнсніLd, I. (1965a) The corpus luteum-hypophysis relationship; The luteolytic effect of luteinizing hormone (LH) in the rat. Acta endocr., Copenh. 49, 107.

RoтнсніLD, I. (1965b) Interrelations between progesterone and the ovary, pituitary, and central nervous system in the control of ovulation and the regulation of progesterone secretion. Vitams Horm. 23, 209.

Steel, R. G. D. \& Torrie, J. H. (1960) Principles and procedures of statistics. McGraw-Hill, New York. 